\title{
Accelerated collagen cross-linking in the management of advanced Acanthamoeba keratitis
}

\author{
Cross-linking acelerado de colágeno no controle da ceratite por \\ Acanthamoeba avançada
}

\author{
Cartes Cristian', Casas del Valle Marco², Kantor Arturo², Pérez Claudio², Srur Miguel², Raimann Rolf², \\ López Remigio3, Traipe Leonidas² \\ 1. Clínica Universidad de los Andes, Universidad de los Andes, Santiago, Chile. \\ 2. Fundación Oftalmológica Los Andes, Universidad de los Andes, Santiago, Chile. \\ 3. Cellular and Molecular Biology Program, Faculty of Medicine-ICBM, Universidad de Chile, Santiago, Chile.
}

\begin{abstract}
Purpose: To report our initial experience in the treatment of Acanthamoeba keratitis with accelerated corneal collagen cross-linking. Methods: Retrospective chart review of patients diagnosed with Acanthamoeba keratitis with progressive corneal melting who were treated with accelerated collagen cross-linking. Results: A total of 6 eyes (5 patients) were reviewed. All the patients received adjuvant therapy with moxifloxacin and chlorhexidine. In 4 cases, the ulcer healed with a mean interval to epithelialization of 108.8 days (range 59-217). In 2 eyes, there was a persistent neurotrophic ulcer. The melting was not progressive in any case, nor did any eye required emergency penetrating keratoplasy. Conclusion: This study suggests a beneficial effect of accelerated collagen cross-linking in cases of Acanthamoeba keratitis with corneal melting. Thus, collagen cross-linking may be considered as adjuvant treatment for Acanthamoeba keratitis.
\end{abstract}

Keywords: Cross-linking reagents; Acanthamoeba keratitis; Corneal ulcer; Collagen

RESUMO | Objetivo: Relatar nossa experiência inicial no tratamento da ceratite por Acanthamoeba com reticulação acelerada de colágeno corneano. Métodos: Revisão retrospectiva de prontuários de pacientes diagnosticados com ceratite por Acanthamoeba, com deformação progressiva da córnea, tratados com reticulação acelerada de colágeno. Resultados: Seis olhos (5 pacientes) foram incluídos. Todos os pacientes receberam terapia adjuvante com moxifloxacina e clorexidina. Em 4 casos,

Submitted for publication: April 10, 2017

Accepted for publication: June 22, 2018

Funding: No specific financial support was available for this study.

Disclosure of potential conflicts of interest: None of the authors have any potential conflicts of interest to disclose.

Corresponding author: Cristián Cartes.

Avenida Plaza 2501 - Santiago, Chile - E-mail: ccartesindo@gmail.com

Approved by the following research ethics committee: Fundación Oftalmológica los

Andes. a úlcera cicatrizou com uma média de epitelização de 108,8 dias (amplitude de 59-217 dias). Em dois pacientes, a úlcera apresentou um comportamento neurotrófico. A deformação não foi progressiva em nenhum dos pacientes e nenhum dos olhos exigiu ceratoplastia penetrante de emergência. Conclusão: Este estudo sugeriu um efeito benéfico da reticulação acelerada de colágeno em casos de ceratite por Acanthamoeba infecciosa com deformação corneal. A reticulação de colágeno parece ser uma alternativa coadjuvante possível para casos de ceratite por Acanthamoeba.

Descritores: Reagentes para ligações cruzadas; Ceratite por Acanthamoeba; Úlcera de córnea; Colágeno

\section{INTRODUCTION}

Infectious keratitis is a disease that, if not treated in time, can lead to corneal ulcers and eventual sight loss. Protozoa of the genus Acanthamoeba can cause keratitis that is very difficult to manage ${ }^{(1,2)}$. Acanthamoeba keratitis (AK) generally requires long and uncomfortable treatment with biguanide or chlorhexidine ${ }^{(1)}$. However, some cases of severe disease do not respond to these agents and may require an emergency corneal transplant.

Collagen cross-linking (CLX) is a procedure using riboflavin and ultraviolet-A (UV-A) radiation to induce biochemical stiffening of the cornea. It is commonly used to treat keratoconus ${ }^{(3)}$. Recent studies indicate that CLX may be effective as a noninvasive alternative therapy for refractory infectious keratitis, obviating the need for emergency surgical procedures in some cases $^{(4,5)}$. Riboflavin and UV-A induce changes in collagen due to photochemical reaction that produces covalent bonds and cross-links between collagen fibrils. This stiffens the corneal stroma, stabilizing it and making it more resistant to enzymatic bacteria degradation, ultimately 
reducing the progression of corneal melting ${ }^{(6,7)}$. Several studies have indicated that these agents may also produce an antimicrobial effect by inducing oxidative damage to DNA and RNA(8).

The Dresden CLX method is the standard for treating infectious keratitis. In this procedure, the stromal cornea is soaked with riboflavin, followed by application of UV-A at $3 \mathrm{~mW} / \mathrm{cm}^{2}$ for 30 minutes, corresponding to a total energy of $5.4 \mathrm{~J} / \mathrm{cm}^{2(9)}$. However, faster alternatives with higher energy and reduced exposure time have been introduced. At present, although this accelerated cross-linking (A-CXL) produces a photochemical effect similar to that of the standard procedure, the biological response in terms of the depth of the effect, changes in collagen, and cell death has not been assessed fully ${ }^{(10)}$.

CLX has been reported to be an effective treatment for AK, but the evidence is limited, as it is derived from clinical reports and case series with small numbers of patients treated with the standard protocol ${ }^{(11,12)}$. However, in vitro and histopathologic findings in both animal and human studies have been conflicting ${ }^{(2,13)}$.

The purpose of this study was to report our initial experience treating AK with A-CLX.

\section{METHODS}

This is a retrospective, noncomparative review of a case series. We evaluated the records of all cases between January 2010 and December 2015 of Acanthamoeba corneal ulcer with progressive corneal melting that were treated with A-CLX (Avedro, Burlington MA). A total of 8 eyes (7 patients) were identified. However, because 2 patients were followed for less than 1 month, they were excluded from the final analysis. The diagnosis of AK was based on cultures performed at the National Institute of Health (Chile).

The data recorded included best corrected visual acuity (BCVA) measured pre- and post-treatment, any treatment prior to A-CXL, ulcer size, adjuvant treatment, time to epithelialization, complications, and whether penetrating keratoplasty (PKP) was performed either acutely or later in the course.

The study was conducted according to established ethical standards for clinical research and the Institutional Review Board of Fundación Oftalmológica Los Andes, Santiago, Chile approved the study.

\section{RESULTS}

We present the results of 5 patients (Table 1) with 6 cases of AK. All were women with a mean age of 58.2 \pm 2.8 years. The ulcer was unilateral in all the cases except that patient 5 had AK in both eyes simultaneously. All the patients wore contact lenses. Table 1 describes treatment prior to A-CLX. The mean interval between the diagnosis of infectious keratitis and A-CLX was 57 days (range 22-128 days). In patients 2, 3, and 5, the initial culture results were negative; therefore, the diagnosis of AK was not known before A-CLX was performed. Material for a repeat culture was obtained in the operating room before the procedure. Subsequently, the culture results were positive for Acanthamoeba. The mean follow-up after A-CLX was 30.4 months (range 24-53 months). AK did not recur in any eye.

Table 1. Clinical data of patients with Akanthamoeba keratitis treated with accelerated collagen cross-linking

\begin{tabular}{|c|c|c|c|c|c|c|c|c|c|c|c|}
\hline Patient & $\begin{array}{l}\text { Age } \\
\text { (yr.) }\end{array}$ & $\begin{array}{l}\text { Previous } \\
\text { treatment }\end{array}$ & Comorbidities & $\begin{array}{c}\text { BCVA } \\
\text { pre-A-CXL }\end{array}$ & $\begin{array}{c}\text { Ulcer } \\
\text { size/ } \\
\text { location }\end{array}$ & $\begin{array}{c}\text { BCVA } \\
\text { final }\end{array}$ & $\begin{array}{l}\text { Treatment } \\
\text { after A-CXL }\end{array}$ & $\begin{array}{c}\text { Time to } \\
\text { epithelialization } \\
\text { (days) }\end{array}$ & PKP & $\begin{array}{l}\text { Follow-up } \\
\text { (months) }\end{array}$ & Complications \\
\hline 1 & 60 & Chl, Mox & $\begin{array}{l}\text { Previous PKP, } \\
\text { Acanthamoeba }\end{array}$ & LP & $\begin{array}{l}5 \mathrm{~mm} / \\
\text { central }\end{array}$ & $\mathrm{HM}$ & Chl, Mox Tob & 217 & - & 27.2 & - \\
\hline 2 & 62 & Mox, Amk & $\begin{array}{l}\text { Congenital facial } \\
\text { palsy, Glaucoma }\end{array}$ & 0.20 & $\begin{array}{c}\text { n.a/ } \\
\text { central }\end{array}$ & 0.2 & Chl, Mox & $\mathrm{NU}$ & 1 & 26.0 & - \\
\hline 3 & 83 & $\begin{array}{l}\text { Cef, mox } \\
\text { Ket }\end{array}$ & $\begin{array}{l}\text { Glaucoma Central } \\
\text { vein occlusion }\end{array}$ & NLP & $\begin{array}{l}9 \mathrm{~mm} / \\
\text { central }\end{array}$ & NLP & Chl mox, Ket & 83 & - & 53.4 & - \\
\hline 4 & 55 & $\begin{array}{l}\text { Chl, Mox, } \\
\text { Vor }\end{array}$ & & 0.25 & $\begin{array}{l}5 \mathrm{~mm} / \\
\text { central }\end{array}$ & 0.4 & Chl, Mox, Ket & 59 & - & 27.3 & - \\
\hline \multirow[t]{2}{*}{5} & 57 & $\begin{array}{l}\text { Mox, Van } \\
\text { in both } \\
\text { eyes }\end{array}$ & $\begin{array}{l}\text { Bilateral limbal } \\
\text { cell deficiency }\end{array}$ & $\mathrm{CF}$ & $\begin{array}{c}\text { n.a / } \\
\text { central }\end{array}$ & 0.05 & Chl, Mox & 76 & 1 & 24.2 & Cataract \\
\hline & & & & 0.05 & $\begin{array}{c}\text { n.a./ } \\
\text { central }\end{array}$ & 0.12 & Chl, Mox & NU & 1 & 24.2 & Cataract \\
\hline
\end{tabular}

$\mathrm{NLP}=$ no light perception; $\mathrm{LP}=$ light perception; $\mathrm{HM}=$ hand motion; $\mathrm{CF}=$ counting fingers; $\mathrm{NU}=$ neurotrophic ulcer; $\mathrm{PKP}=$ penetrating keratoplasty; Chl= chlorhexidine; Van= vancomycin; Cef= cefazolin; Amk= amikacin; Tob= tobramycin; Ket= ketoconazole; Vor= voriconazole; n.a.= not available. 
Two different protocols of A-CLX were used. The first, for all except patient 3, consisted of 10 minutes of impregnation with $0.1 \%$ riboflavin solution followed by 20 minutes of UV-A exposure $\left(4.5 \mathrm{~mW} / \mathrm{cm}^{2}\right)$. The second protocol for patient 3 consisted of 5 minutes of impregnation with $0.1 \%$ riboflavin solution followed by 10 minutes of UV-A exposure $\left(9 \mathrm{~mW} / \mathrm{cm}^{2}\right)$. The total amount of energy applied, $5.4 \mathrm{~J} / \mathrm{cm}^{2}$, was the same in both of the protocols.

After A-CLX, the ulcer healed in 4 eyes with a mean time to epithelialization of 108.8 days (range 59-217 days). In 2 eyes, the ulcer was inactive but persisted as a neurotrophic ulcer. Corneal melting was not progressive in any patient, and no eye required emergency PKP. However, 3 patients had dense central corneal scars requiring subsequent PKP to improve visual acuity. No patient had a post-treatment BCVA that was worse than the pretreatment value. Treatment with chlorhexidine $(0.02 \%)$ and moxifloxacin $(0.5 \%)$ was continued after A-CLX in all the patients until there was complete epithelialization of the ulcer.

\section{DISCUSSION}

AK is a sight-threatening condition that requires difficult and prolonged treatment. The infection and accompanying inflammatory reaction may lead to ulceration, corneal melting, and perforation if not treated adequately. CXL may useful for the treatment of infectious keratitis with corneal melting ${ }^{(14)}$. However, there are a limited number of cases reported in the literature of AK treated with CXL, describing either case series or case reports. In a recently published meta-analysis, 10 out of 11 cases of AK healed, 5 of them with retreatment and with time to epithelialization that ranged from 10 to 99 days ${ }^{(12)}$. In our series, no patient was retreated, although the time until epithelization was prolonged. Progression of melting was avoided in all the cases; however, 2 patients with a previous diagnosis of facial palsy and limbal stem cell deficiency had persistent neurotrophic ulcers.

The antiamebic efficacy of CXL has been evaluated in studies of animal models ${ }^{(2,15)}$ with CXL having no reported efficacy to decrease the intensity and severity of AK. However, animal models of this disease do not have the same characteristics as acute Acanthamoeba infections in humans. For example, Barra et al. injected an extremely high number of parasites into rabbit eyes and found no difference between CXL-treated eyes and infected control eyes. However, they did not report the depth of injection ${ }^{(2)}$.
There are no studies of CXL evaluating when and with how much energy to treat AK. In vitro studies of bacterial cultures report contradictory results. Backman et al. found that an accelerated treatment was less effective at eradicating Staphylococcus epidermis in a film suspension than a 60-min treatment with standard UV-A irradiance $^{(16)}$. Richoz et al. found that accelerated treatments ( $5 \mathrm{~min}$ at $18 \mathrm{~mW} / \mathrm{cm}^{2}$ or $2.5 \mathrm{~min}$ at $36 \mathrm{~mW} / \mathrm{cm}^{2}$ ) both killed approximately $93 \%$ of Staphylococcus aureus or Pseudomonas aeruginosa ${ }^{(17)}$.

Another factor to consider is the depth of the infection within the cornea. UV-A light is absorbed as it passes through the cornea; therefore, treatment efficacy decreases with increasing depth of the lesion ${ }^{(18)}$. The standard CLX protocol produces an effective treatment depth of approximately 250 to $300 \mu \mathrm{m}^{(19)}$. This may explain in part why the treatment is not effective in advanced cases.

There is no evidence in the literature supporting a recommendation to use A-CXL instead of traditional therapy for treating AK. However, we think that, in the management of infectious keratitis with progressive corneal melting, the use of CLX could be a valuable adjunct to other measures. To confirm this view, further investigation is needed as to how factors such as corneal thickness and depth of infection affect the outcome.

\section{REFERENCES}

1. Khan NA. Acanthamoeba: biology and increasing importance in human health. FEMS Microbiol Rev. 2006;30(4):564-95.

2. Berra M, Galperín G, Boscaro G, Zarate J, Tau J, Chiaradia P, et al. Treatment of Acanthamoeba keratitis by corneal cross-linking. Cornea. 2013;32(2):174-8. doi: 10.1097/ICO.0b013e31825cea99. Comment in: Cornea. 2013;

3. Spoerl E, Huhle M, Seiler T. Induction of cross-links in corneal tissue. Exp Eye Res. 1998;66(1):97-103.

4. Bettis DI, Hsu M, Moshirfar M. Corneal collagen cross-linking for nonectatic disorders: a systematic review. J Refract Surg [Internet]. 2012[cited 2017 nov 21];28(11):798-807. Available from: http://www.healio.com/ophthalmology/journals/ jrs/2012-11-28-11/\{0573c5ac-bf75-49d6-bb42-8f164c2e6703\}/ corneal-collagen-cross-linking-for-nonectatic-disorders-a-systematicreview.pdf

5. Skaat A, Zadok D, Goldich Y, Varssano D, Berger Y, Ezra-Nimni O, et al. Riboflavin/UVA photochemical therapy for severe infectious keratitis. Eur J Ophthalmol. 2014;24(1):21-8. doi: 10.5301/ejo.5000330

6. Spoerl E, Wollensak G, Seiler T. Increased resistance of crosslinked cornea against enzymatic digestion. Curr Eye Res. 2004;29(1):35-40.

7. Schilde T, Kohlhaas M, Spoerl E, Pillunat LE. [Enzymatic evidence of the depth dependence of stiffening on riboflavin/UVA treated corneas]. Ophthalmologe [Internet]. 2008[cited 2017 jan 21];105(2): 165-9. Available from: http://link.springer.com/10.1007/s00347007-1587-9\nhttp://www.ncbi.nlm.nih.gov/pubmed/17955247

8. AuBuchon JP, Herschel L, Roger J, Taylor H, Whitley P, Li J, et al. Efficacy of apheresis platelets treated with riboflavin and ultravio- 
let light for pathogen reduction. Transfusion. 2005;45(8):1335-41. doi:10.1111/j.1537-2995.2005.00202.x

9. Wollensak G, Spoerl E, Wilsch M, Seiler T. Endothelial cell damage after riboflavin-ultraviolet-A treatment in the rabbit. J Cataract Refract Surg. 2003;29(9):1786-90.

10. Santhiago MR. Accelerated corneal cross-linking: we must acquire knowledge as fast. J Refract Surg. 2016;32(6):362-3. doi: 10.3928/ 1081597X-20160519-01.

11. Khan YA, Kashiwabuchi RT, Martins SA, Castro-Combs JM, Kalyani S, Stanley P, et al. Riboflavin and ultraviolet light a therapy as an adjuvant treatment for medically refractive Acanthamoeba keratitis: report of 3 cases. Ophthalmology. 2011;118(2):324-31. doi: 10.1016/j.ophtha.2010.06.041.

12. Papaioannou L, Miligkos M, Papathanassiou M. Corneal collagen cross-linking for infectious keratitis: a systematic review and meta-analysis. Cornea. 2016;35(1):62-71. doi: 10.1097/ICO. 0000000000000644.

13. Hager T, Hasenfus A, Stachon T, Seitz B, Szentmáry N. Crosslinking and corneal cryotherapy in acanthamoeba keratitis -- a histological study. Graefes Arch Clin Exp Ophthalmol. 2016;254(1):149-53.

14. Said DG, Elalfy MS, Gatzioufas Z, El-Zakzouk ES, Hassan MA, Saif MY, et al. Collagen cross-linking with photoactivated riboflavin
(PACK-CXL) for the treatment of advanced infectious keratitis with corneal melting. Ophthalmology. 2014;121(7):1377-82. doi: 10.1016/j.ophtha.2014.01.011.

15. Kashiwabuchi RT, Carvalho FRS, Khan YA, de Freitas D, Foronda AS, Hirai FE, et al. Assessing efficacy of combined riboflavin and UV-A light $(365 \mathrm{~nm})$ treatment of acanthamoeba trophozoites. Investig Ophthalmol Vis Sci. 2011;52(13):9333-8. doi: 10.1167/ iovs.11-8382.

16. Bäckman A, Makdoumi K, Mortensen J, Crafoord S. The efficiency of cross-linking methods in eradication of bacteria is influenced by the riboflavin concentration and the irradiation time of ultraviolet light. Acta Ophthalmol. 2013;92(7)656-61.

17. Richoz O, Kling S, Hoogewoud F, Hammer A, Tabibian D, Francois $\mathrm{P}$, et al. Antibacterial efficacy of accelerated photoactivated chromophore for keratitis-corneal collagen cross-linking (PACK-CXL). J Refract Surg. 2014;30(12):850-4. doi: 10.3928/1081597X-20141118-01.

18. Price MO, Price FW. Corneal cross-linking in the treatment of corneal ulcers. Curr Opin Ophthalmol. 2016;27(3):250-5. doi: 10.1097/ ICU.0000000000000248.

19. Sporl E, Schreiber J, Hellmund K, Seiler T, Knuschke P. [Studies on the stabilization of the cornea in rabbits]. Ophthalmologe. 2000; 97(3):203-6. German. 